\title{
Zmienne barwy Lipska
}

Artykuł pokazuje złożoną historię unitów w Lipsku nad Biebrzą. Autor pokazuje także stosunki międzywyznaniowe na tym obszarze na przestrzeni wieków. Analizuje również genezę kształtowania mozaiki kulturowej i religijnej w tym regionie. Bada stan wiedzy mieszkańców regionu o przeszłości. Autor pisze o tym, jak wieloetniczna i wielokulturowa przestrzeń stopniowo przekształciła się w obszar jednolity religijnie i kulturowo.

Słowa kluczowe: Lipsk, stosunki religijne, unici, prawosławni, katolicy

O Lipsku nad Biebrzą napisano już niemało. Sprawa sama w sobie jest godna uznania, a dla miłośników tego uroczego zakątka Białostocczyzny - bez wątpienia pasjonująca. Żadne bowiem historyczne uogólnienia nie są tak komunikatywne, nie zawierają tak dużego ładunku poznawczego i emocjonalnego jak dzieje konkretnej miejscowości skrupulatnie odtwarzane w wyniku szperackiej działalności zainteresowanych jednostek czy zespołów.

To zainteresowanie wydaje się mieć dostateczne uzasadnienie. Obok wielu dziedzin życia w większym lub mniejszym stopniu typowych dla licznych środowisk, dzieje Lipska mają swoistą specyfikę i obfitują w wydarzenia nie mające analogii w innych regionach kraju. Należy do nich w szczególności złożony i ciekawy historyczny proces kształtowania się społeczności tego nanbiebrzańskiego grodu osnuty na podłożu zróżnicowanych struktur kulturowych charakterystycznych dla etnicz- 
nego i wyznaniowego pogranicza. W tej zaś dziedzinie dotychczasowy dorobek publicystyczny jest raczej ubogi.

Niejako więc w uzupełnieniu tej luki wypada zauważyć, iż w historycznie udokumentowanym historycznym procesie formowania się tej społeczności uczestniczyły dwa nurty ludnościowe o odmiennym pochodzeniu i wyznaniu. Jak wskazują najwcześniejsze dane, już w XVI stuleciu istniały tu obok siebie Kościół rzymskokatolicki i Cerkiew prawosławna będące ośrodkami dwóch odrębnych parafii dla ludności Lipska i najbliższych okolic. Jak i kiedy powstały obie parafie lipskie?

W Lipsku istniało też niewielkie skupisko ludności żydowskiej (87 osób w 1921 r.), która nie uczestniczyła w procesie kulturowej integracji i aż do jej wyniszczenia przez hitlerowców w 1942 r. zachowała odrębność językową i wyznaniową oraz własne tradycje.

Nie jest trudna do ustalenia geneza parafii rzymskokatolickiej. Bazą do jej utworzenia była ludność przybyła tu na fali tzw. osadnictwa nadniemeńskiego, które dokonało się w zasadzie w ciągu XVI stulecia. Ludność ta, zasiedlając środkową i zachodnia Sokólszczyznę a także przyległe okolice, przyniosła za sobą zarówno akającą mowę białoruską, jak i rzymskokatolickie wyznanie, czego wyrazem była sieć kościołów fundowanych przez królów polskich i możnowładców w większych skupiskach osadzających się wśród puszcz przybyszów. Tak więc w ciągu XVI stulecia powstają kościoły w Sokółce (1592 r.), Kuźnicy (1541 r.), Kundzinie (1562 r.), Korycinie (1602 r.), Suchowoli (1591 r.), Sidrze (1535 r.) i in. W tym też czasie - w 1582 r. powstaje kościół w Lipsku, którego fundatorem był Stefan Batory.

Inną natomiast miała być geneza lipskiej parafii prawosławnej, zważywszy, iż nie mogła ona być rezultatem tej szesnastowiecznej kolonizacji nadniemeńskiej, w zasięgu której powstawały nie cerkwie, lecz kościoły. Wiele wskazuje na to, iż powstała ona na tle tzw. osadnictwa nadbużańskiego - wielkiej kolonizacyjnej fali polesko-wołyńskiej ludności ruskiej, która w ciągu XIV i XV stulecia zasiedliła historyczną ziemię mielnicką oraz wschodnie połacie ziemi drohickiej i bielskiej, dochodząc zwartą masą do rzeki Supraśl pomiędzy Wasilkowem i jej 
ujściem do Narwi. W dalszym swym procesie osadnictwo to przekroczyło rzekę Supraśl, sięgając aż po Augustów, jednakże na tym obszarze występowało ono już tylko w postaci niewielkich izolowanych skupisk wśród przeważającego tu, głównie mazowieckiego, żywiołu.

Pomnikami tej dawnej kolonizacji nadbużańskiej były przez kilka stuleci rozsiane na znacznej przestrzeni cerkwie, o których istnieniu świadczą dziś już tylko historyczne źródła. Wśród nich można wymienić istniejące w XVI stuleciu cerkwie w Wysokiem Mazowieckiem, Surażu, Hodyszewie, Tykocinie, Boguszewie, Knyszynie, Augustowie, Balli Cerkiewnej (później Balla Kościelna) [obecnie Zaračanka, rejon grodzieński. - Red.]. W ich liczbie była też zbudowana przez Chrebtowiczów w Lipsku cerkiew od wezwaniem Matki Boskiej Przeczystej, która już w 1569 r. uposażona została w dwie włóki. W ten sposób zetknęły się nad brzegiem Biebrzy placówki Rzymu i Konstantynopola - dwa żywioły odmienne w swej kulturowej tradycji, których współistnienie było istotnym wyznacznikiem w rozwoju społeczności Lipska.

Pierwsze ważne przekształcenie w tym względzie przynosi już koniec XVI stulecia. Na mocy uchwał soboru brzeskiego z 1596 r. lipska parafia prawosławna przyjmuje unię kościelną, nie różniąc się w ten sposób od większości cerkwi na Białostocczyźnie. Przesunięcie to miało jednak charakter organizacyjny i doktrynalny (akceptacja dogmatyki katolickiej) i praktycznie biorąc, nie spowodowało istotnych zmian w obrzędowości i stosowaniu języka cerkiewno-słowiańskiego. Pomimo jednak zachowania obrzędowości wschodniej, unia stała się ważnym czynnikiem wpływającym na kształtowanie się harmonijnego współżycia obu grup lipskiej społeczności i rozwiązywanie licznych codziennych problemów życiowych. W szczególności znosiła ona przeszkody na drodze zawierania małżeństw pomiędzy członkami rzymskokatolickiej i unickiej, różniących się już tylko obrządkiem, a nie względami natury doktrynalnej. Wprawdzie o tej ostatniej prości ludzie szczegółowego pojęcia przypuszczalnie nie mieli, niemniej miało je duchowieństwo obu obrządków, co było czynnikiem w praktyce decydującym. 
Nierzadko przedstawiane są opinie, iż historyczną misją unii była latynizacja wyznawców prawosławia. Przykład Lipska jest w danym wypadku szczególnie interesujący, zważywszy że oba odłamy jego ludności tworzyły układ dość nierówny. Wynikał on nie z liczebności parafii unickiej (była ona dostatecznie duża), lecz z faktu znacznej jej terytorialnej izolacji, przez co była ona narażona na rozkład wewnętrzny w stopniu bez porównania większym niż parafie powstałe w zasięgu zwartego osadnictwa nadbużańskiego. Oszczędzając licznych wywodów teoretycznych w tej materii, wypada zwrócić uwagę na fakt, iż mimo wspomnianych mało korzystnych warunków, unicka parafia w Lipsku przetrwała blisko trzysta lat, przy czym aż do połowy XIX wieku nie wystąpiły tu odczuwalne procesy rozkładowe. Było to wynikiem nie tylko przywiązania ludności do tradycyjnego obrządku, lecz także - i to w stopniu na pewno większym - skutkiem papieskiego zakazu przeciągania unitów na łono Kościoła rzymskokatolickiego. Nietrudno więc wyobrazić, iż szanse tej ludności Lipska na zachowanie obrzędowości wschodniej byłyby w warunkach prawosławia daleko mniejsze: w dziedzinie bowiem nawracania innowierców duchowieństwo katolickie nie było krępowane żadnymi zakazami.

Upadek I Rzeczypospolitej i następujący bezpośrednio po nim krótkotrwały okres panowania pruskiego na Białostocczyźnie (1795-1806) nie spowodował żadnych istotnych zmian w dwubarwnym układzie lipskiej społeczności. Nadal więc istnieją tu obok siebie dwie parafie, z których unicka liczyła na początku XIX stulecia 1820 wierzących, będąc największą parafią ówczesnego dekanatu nowodworskiego. Również w samym Lipsku ludność unicka nie była marginesem demograficznym. Jak wynika z retrospektywnego szacunku, na początku XIX wieku jej liczba była w przybliżeniu równa liczebności rzymskokatolickich jego mieszkańców.

Radykalny zwrot w tej sytuacji zapoczątkowany został dopiero około połowy XIX stulecia, od kiedy notuje się raptowny rozkład unickiej parafii w Lipsku. Bezpośrednim tego impulsem stała się likwidacja unii kościelnej dokonana w 1839 r. na terenie białoruskich i ukraińskich 
guberni wchodzących w skład Cesarstwa Rosyjskiego. W procesie tym, służącym politycznym celom caratu i realizowanym zarówno przez władze duchowne, jak i administracyjne, nie przebierano w środkach: przyłączania unitów do prawosławia następowało automatycznie na podstawie uchwały soboru w Połocku, a desperackie nieraz akty oporu załatwiano przy pomocy policji i kozackich nahajek.

W Lipsku i innych parafiach położonych na obszarze Królestwa Polskiego unię skasowano dopiero w 1875 r. Tak więc w 36-letnim okresie dzielącym obie te daty lipscy unici mieli sporo czasu do przemyśleń co mają począć w obliczu grożącej likwidacji ich kościoła. Alternatywa była niby prosta - albo wyznanie rzymskokatolickie, albo przyjęcia prawosławia. W praktyce jednak decyzja w tej sprawie była niezwykle trudna, na co wpływały bądź obiekcje doktrynalne, bądź obrzędowe, a także - z pewnością w niemałym stopniu - metody likwidacji unii stosowane przez władze na terenie cesarstwa. Stąd też i rozstrzygnięcia nie były jednolite. Część lipskich unitów, asekurując się przed spodziewanym włączeniem do prawosławia już w latach 1839-1875, przyjęła obrzędowość łacińską, pozostali zaś zajęli pozycję wyczekującą, łudząc się nadzieją na zachowanie dotychczasowego układu.

Rok 1875 zapoczątkował w dziejach lipskiej społeczności serię doniosłych wydarzeń, praktycznie biorąc przesądzających o wykształceniu się jej współczesnego oblicza. Dokonana w tym czasie kasacja unii w Królestwie Polskim zburzyła jednym pociągnięciem pióra istniejący od bez mała trzech stuleci układ społeczny, zobowiązując zarazem wszystkich unitów do ,powrotu” do wyznania ich szesnastowiecznych przodków. W tej sytuacji rozwiały się całkowicie nadzieje lipskich unitów na rozwiązania alternatywne, jednakże na jakiekolwiek działanie było już za późno. W porę uświadomił to sobie ich ostatni proboszcz ks. Jakub Szydłowski, chroniąc się w lutym 1875 r. przed duchowym gwałtem aż w Galicji. Rzecz jasna, iż na takie wyjście z sytuacji nie mogła sobie pozwolić duża część ludności Lipska, która musiała pozostać na miejscu.

W tych warunkach na gruzach unii rozpoczęto w Lipsku organizację nowej parafii prawosławnej. W jej skład musieli wejść trwający do 
końca przy swoim obrzędzie unici. Było ich jednak już niezbyt wiele, w związku z czym przybyły tu prawosławny proboszcz ks. Michał Wigura rozpoczął nienotowany dotychczas nad Biebrzą proces polowania na dusze, polegający na wyszukiwaniu i nawracaniu na prawosławie tych unitów, którzy w latach poprzednich przeszli na obrządek łaciński.

Stworzona przy pomocy czynników administracyjnych i w warunkach - delikatnie mówiąc - całkowitego braku entuzjazmu wśród miejscowej ludności nowa parafia była tylko formalnie prawosławna, faktycznie zaś jej członkowie nieustannie oglądali się na Kościół. Nie pomagały ni przekonywania, ni groźby. W tej sytuacji postanowiono ograniczyć konkurencję mechanicznie: w końcu 1875 r. decyzją władz gubernialnych zniesiono samodzielną rzymskokatolicką parafię w Lipsku, pozostawiając jednak kościół jako filialny. Jednocześnie w celu stworzenia zachęty dla byłej unickiej ludności i podniesienia prestiżu prawosławia, przystąpiono w Lipsku do budowy za rządowe pieniądze nowej cerkwi, którą oddano do użytku w 1880 r. Była to murowana o oryginalnym stylu świątynia, jedna z największych i najpiękniejszych, jakie istniały na Białostocczyźnie.

Jednakże zabiegi te - jak to się nierzadko zdarza - przyniosły efekt społeczny raczej odwrotny w stosunku do zamierzeń ich autorów. Wielka efektowna cerkiew stała pustawa, a opór ludności rósł i zataczał coraz szersze kręgi, powodując oczywistą irytację lipskiego proboszcza i jego władz eparchialnych. Na ich też wniosek w 1886 r. suwalskie władze gubernialne podjęły decyzję zburzenia lipskiego kościoła, w którym upatrywano największą przeszkodę na drodze do restytucji prawosławia nad Biebrzą. Wobec obronnej postawy ludności Lipska realizacja tego przedsięwzięcia wcale nie była łatwa i długo pozostała w pamięci jego mieszkańców. Nie mogli zburzyć lipską świątynię przysłani robotnicy, których przepędzono obrzucając kamieniami i jajkami. Dzieła tego dokonał dopiero w starciu z ludnością przybyły tu oddział kozaków pozostawiając na pobojowisku licznych zabitych i rannych. Dla uczczenia ich pamięci wzniesiono tu później wielki kopiec, stojący po dzień dzisiejszy. 
Pozostawiając na boku emocjonalną ocenę tego posunięcia władz carskich, wypada zauważyć, iż miało ono na celu skutki znacznie głębsze. Nietrudno bowiem uzmysłowić, jakie uczucia żywiła katolicka ludność Lipska w obliczu takiego obejścia się z jej świątynią. Uczucia te zwracały się nie tylko przeciw carskiej czarnej sotni jako bezpośredniemu sprawcy, lecz także przeciw faworyzowanym prawosławnym współziomkom. Prowokowanie antagonizmu wyznaniowego, wypróbowane $\mathrm{z}$ nienajgorszym skutkiem w innych okolicach Białostocczyzny miało bowiem, zgodnie z zamierzeniem władz, spowodować zwiększenie nacisku społecznego na członków parafii prawosławnej, którzy z kolei powinni byli szukać pomocy i wsparcia w reżymie carskim, mieniącym się przecież obrońcą prawosławia.

Mogłoby się wydawać, iż stworzony w ten sposób w końcu XIX stulecia nowy układ w Lipsku nie mącił już snu ani prawosławnemu proboszczowi, ani jego władzom. Według danych przeprowadzonego w 1897 r. spisu, liczba ludności prawosławnej w Lipsku sięgała 451 osób, stanowiąc prawie 40\% całej jego chrześcijańskiej ludności. Wynik był więc całkiem znośny, a bezpieczeństwu dusz cerkiewnej społeczności nie zagrażała już żadna agitacja z kościelnej ambony. O niczym też, poza ciszą i spokojem, nie donosił przez wiele lat oficjalny «Холмско-варшавский епархиальный вестник», który nie dostrzegał czy nie chciał dostrzegać w Lipsku napięcia o niebywałych do tej pory rozmiarach.

Na jego eksplozję nie trzeba było czekać długo. Carski manifest o tolerancji wyznaniowej z 1905 r. spowodował w tej nadbiebrzańskiej miejscowości wyjątkowo gwałtowne rozładowanie atmosfery stworzonej w ciągu poprzedniego trzydziestolecia drogą brutalnych nacisków i prowokacji, a także niemałych nakładów finansowych. W najkrótszym czasie po ogłoszeniu carskiego manifestu niemal wszyscy członkowie prawosławnej parafii przeszli na katolicyzm, przyczyniając się zarazem do budowy w rekordowym tempie nowego kościoła. W tej sytuacji, jesienią 1905 r. opuszcza Lipsk najpierw cerkiewny psalmista Aleksander Lisuk-Lisowski, a nieco później - jego prawo- 
sławny proboszcz ks. Andrzej Serączkowski. Na lipskim placu boju pozostał więc tylko Kościół katolicki, bez trudu dyskontując owoce polityki caratu.

Władzom warszawskiej eparchii pozostało w tych warunkach już tylko zachowanie twarzy, rzecz jasna nie wobec mieszkańców Lipska, lecz przed Świętym Synodem i władzami cywilnymi. Tym podyktowane były próby utrzymania parafii chociażby na papierze. W marcu $1906 \mathrm{r}$. skierowany został do Lipska sopoćkiński wikariusz ks. Aleksander Aleksiejewicz, który pełnił funkcję proboszcza do stycznia 1908 r., a po jego wyjeździe przysłano tu jeszcze ks. Sergiusza Czerniachowskiego. Jednakże względy prestiżowe nie mogły usprawiedliwić nakładów na utrzymanie parafii, w której duchowni, praktycznie biorąc, nie mieli nic do roboty, tym bardziej iż wysiłki te nie rokowały też żadnych nadziei na przyszłość. Stąd ukazem Świętego Synodu z 17 grudnia 1908 r. została ona oficjalnie zamknięta. Finał ten miał jeden aspekt szczególny: parafia prawosławna w Lipsku była jedyną na Białostocczyźnie, która zakończyła swe istnienie w warunkach rządów carskich.

Po niewczasie przyszło też opamiętanie i samokrytyka. W dniu 27 marca 1905 r., a więc w miesiąc po carskim ukazie o tolerancji, «Холмско-варшавский епархиальный вестник» pisał: „Dlaczego w wielu parafiach zakończyła się fiaskiem próba zjednoczenia [unitów $-J$. T.] w 1875 r.? Głównie dlatego, że w niektórych parafiach zbyt przymusowo przerwano naturalny historyczny proces rozwoju miejscowego życia i narzucono to, co zostało stworzone w warunkach całkowicie odmiennej psychologii. To, co przyszło z zewnątrz pod postacią czystości wielkoruskiego prawosławnego obrządku, oddziaływało na życie miejscowe tak, jak obce ciało, które przypadkowo znalazło się w organizmie".

Cóż, wypowiedź równie uczciwa, jak wyczerpująca i dorzucić do niej można istotnie niewiele. Może jeszcze to, jak wielka i żywotna jest siła oddziaływania ukształtowanych w ciągu stuleci autentycznych miejscowych układów i tradycji. Zwięźle i dobitnie wyraził to w rozmowie $\mathrm{z}$ autorem w maju br. sędziwy lipski staruszek, p. Drabczuk: „Pa- 
nie, żeby nie ta kasacja, to unia byłaby do dziś!...”. Słowa te zawierają wiele - i ocenę własnej przeszłości, i szacunek dla niej.

Na zakończenie tej wycieczki w nadbiebrzańską przeszłość należy dodać, iż opustoszała w 1908 r. cerkiew była przez wiele lat praktycznie biorąc jedynie oryginalnym elementem krajobrazu Lipska. Nie wzbudzała ona wprawdzie przyjemnych wspomnień, jednakże ani jego mieszkańcy, ani nawet władze międzywojenne nie zdecydowały się na jej zburzenie. Co więcej, w połowie lat trzydziestych próbowano cerkiew ożywić nadając jej status tzw. nieetatowej filii, niemniej było to już tylko wyrazem dążenia polskiego kościoła prawosławnego do zachowania budynku świątyni. Została ona rozebrana dopiero w 1940 r. na mocy decyzji lipskich organów władzy radzieckiej, które uznały za niecelowe utrzymywanie tego obiektu - widocznej pamiątki niechlubnych działań carskiego reżymu.

Dzisiejszy Lipsk jest już całkowicie jednobarwny. Umysły jego mieszkańców zaprzątają nowe problemy współczesności. Zatarły się też w pamięci szczegóły wydarzeń, które w pełni zasługują na określenie społecznej integracji osiedlonych tu przed wiekami przedstawicieli dwóch wielkich odmiennych kultur.

Jakie owoce wydała ta integracja w folklorze, obyczajach, sposobie myślenia? Czy rzeczywiście nic już nie pozostało z minionej dwubarwności Lipska? Wdzięczne to bez wątpienia problemy dla badawczej działalności socjologów i historyków kultury ziemi białostockiej.

Przygotował do druku Aliaksei Shota

\section{Variable colors of Lipsk}

The article presents the complex history of the Uniates in Lipsk. The author also shows inter-faith relations in this area over the centuries. Shows the genesis of shaping the cultural and religious mosaic. Analyzes the state of knowledge of the region's inhabitants about the past. The author writes about how the multi-ethnic and multicultural area gradually turned into a unified religious and cultural area.

Keyword s: Lipsk, inter-faith relations, Uniates, Orthodox, Catholics 